\title{
Colonies of Phaeocystis globosa are protected by a thin but tough skin
}

\author{
Christian E. Hamm ${ }^{1, *}$, Doris A. Simson ${ }^{2}$, Rudolf Merkel ${ }^{2}$, Victor Smetacek ${ }^{1}$ \\ ${ }^{1}$ Alfred Wegener Institute for Polar and Marine Research, Postfach 120161, D-27515 Bremerhaven, Germany \\ ${ }^{2}$ Physics Department (Biophysics group), Technische Universität München, Lehrstuhl für Biophysik, E22, \\ D-85748 Garching, Germany
}

\begin{abstract}
Colonies of the prymnesiophyte marine microalga Phaeocystis globosa were tested for mechanical properties, permeability and biochemical composition using the micropipette aspiration technique. We found that the Phaeocystis colony is enclosed by a thin, yet very strong, semi-permeable skin (pore size between 1 and $4.4 \mathrm{~nm}$ diameter) with plastic and to a limited extent also elastic properties. Qualitative staining of single colonies with selective fluorescent dyes indicated absence of lipophilic compounds and chitin but presence of amino groups in the colony skin. Individual cells in the colony appear to be weakly connected with one another and attached to a very dilute, peripheral gel. Suction applied to the colony resulted in volume loss due to expulsion of water and squeezing together of the cells within the skin into a tight pouch; the presence of any firm gelatinous matter within the colony was not discernible. On increasing suction pressure, the skin eventually ruptured and the cells were sucked out of the hole leaving the empty skin behind. We propose that the skin effectively protects the colony cells from grazing and infection by viruses and other pathogens. The unsuspected presence of a skin is probably the main reason why Phaeocystis colonies have reduced mortality relative to solitary cells and form large blooms in many regions of the world's ocean. Our findings indicate that the colonies should be viewed as 'bags of water' rather than 'balls of jelly'
\end{abstract}

KEY WORDS: Phytoplankton colony Phaeocystis - Grazer deterrent · Colony skin - Micropipette aspiration technique

\section{INTRODUCTION}

The marine microalga Phaeocystis is ubiquitous in coastal and shelf areas as well as in nutrient-rich regions of the open ocean and can dominate phytoplankton blooms for extended periods of time (Lancelot et al. 1998). Although its life cycle includes solitary cells and colonies, massive blooms consist almost exclusively of the smooth-surfaced, globose colonies (Lancelot \& Rousseau 1994). Since growth rates of colony cells are reported to be similar to those of solitary cells (Guillard \& Hellebust 1971, Grimm \& Weisse 1985) it follows that accumulation of biomass can only be due to differences in the ratio of the growth/mortality rates between solitary and colonial life stages. Even though this has been long suspected, experimental evidence on the defense strategy of

•E-mail: chamm@awi-bremerhaven.de
Phaeocystis colonies has not been straightforward to obtain. Weisse et al. (1994) reviewed the literature on grazing of Phaeocystis colonies by zooplankton and concluded that the majority of reports indicated lower grazing rates on colonies as compared to other types of phytoplankton including solitary cells. Further, Jacobsen et al. (1996) recorded mass viral infection accompanied by mortality of a population of solitary Phaeocystis cells and hypothesized that colony cells were protected against viruses.

Although the structure of Phaeocystis colonies has been studied since the last century, there is no consensus on presence and location of chemical constituents. Lagerheim (1896) proposed that the colony structure and spherical shape is maintained by a thin, but dense skin, whereas Scherffel (1900) assumed that the whole colony was gelatinous. The latter view of the colonies as 'balls of jelly' as opposed to 'bags of water' is now widely believed. Recently, van Rijssel et al. (1997) 
showed that the colonies are hollow with a gelatinous periphery in which the cells are embedded.

In the present study we examined the mechanical and chemical properties of individual Phaeocystis colonies using the micropipette aspiration technique developed by Mitchison \& Swann for sea urchin eggs (Mitchison \& Swann 1954). The method and its applications - it is also used to examine blood cells (Rand \& Burton 1964) - have been reviewed by Evans (1989) and Needham (1993). The technique enabled us to study the mechanical response and stability of the colony to large forces. Using 2 pipettes, we were able to rapidly transfer individual colonies between different solutions and to thus assess colony permeability as well as chemical constituents of its components by selective fluorescent stains. We used dyes that selectively stain lipids, amino groups, chitin and chitobiose.

The results clearly show that Lagerheim's view of Phaeocystis colony structure is essentially correct. We found that the colonies are enclosed in a very thin, but tough, skin with a dilute gelatinous lining to which the cells appear to be attached. The surprising strength of the skin strongly suggests that it is the major defense mechanism of the colony against grazing and infecting organisms

\section{MATERIAL AND METHODS}

Cultures. Phaeocystis globosa was isolated from the North Sea and cultured at $10^{\circ} \mathrm{C}$ in enriched seawater (f/2) (Guillard \& Ryther 1962). Three days prior to the experiment, the culture was transferred to natural North Sea winter water (taken in February 1997 , osmolarity: 984 mOsm, salinity 33.1) to exclude possible effects of EDTA or high nutrient concentrations. Colonies were grown at $10^{\circ} \mathrm{C}$ in glass bottles under

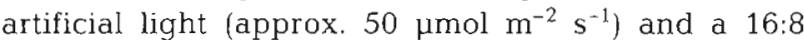
light:dark cycle. Young colonies of appropriate size (50 to $100 \mu \mathrm{m}$ ) for the experiments were grown as described by Cariou et al. (1994). Colonies from the culture were rapidly transferred to the micropipette system or the staining buffers.

Microscopy and micropipette techniques. An inverted microscope (Axiovert 135TV, Carl Zeiss, Jena, Germany) equipped with an Achroplan 20×/0.4 long distance lens (Carl Zeiss) and a long distance condenser was used. Bright field, phase contrast, differential interference contrast (DIC) and fluorescence microscopy were applied as contrast methods. Images were recorded at video rate with a standard CCD camera (C5403-1, Hamamatsu, Hamamatsu City, Japan) and stored on video tape. For fluorescence microscopy a Fluar $40 \times / 1.3$ oil lens and an extremely sensitive SIT camera (C2400-08, Hamamatsu) were used. Fluores- cence was excited with a $100 \mathrm{~W}$ mercury arc lamp, excitation and emission wavelengths were separated with the appropriate filter sets (Zeiss filter set 10/No. 4879210-0000 for blue excitation, excitation: 450-490 nm, dichroic mirror: $510 \mathrm{~nm}$, emission: 515-565 nm; Zeiss filter set 20/No. 487920-0000 for green excitation, excitation $546 \mathrm{~nm}$, bandpass, dichroic mirror: $560 \mathrm{~nm}$, emission: 575-640 nm).

Micropipettes were drawn from borosilicate capillaries (Hilgenberg, Malsfeld, Germany) with a micropipette puller (P-87, Sutter Instrument Company, San Rafael, CA). These raw pipettes had to be opened. This was done under a dissecting microscope by insertion of the pipette tip in a molten drop of soda lime glass, cooling down the glass drop and shearing off the pipette. Such pipettes were of cylindrical shape with an internal diameter between 6 and $15 \mu \mathrm{m}$ and showed no visual irregularities. The pipettes were filled with the respective buffer, inserted into the micromanipulator (MMW-22, Narishige, Tokyo, Japan) and connected to the pressure reservoir. The experiments were performed on the microscope stage in a thermostated chamber that consisted of 2 coverslips held at a distance of $1 \mathrm{~mm}$. The chamber was held at a temperature of $10^{\circ} \mathrm{C}$ by circulation of temperature controlled water. A schematic layout of the setup is shown in Fig 1.

We manipulated 9 Phaeocystis globosa colonies of different size to explore their structure and mechanical properties by subjecting them to suction with the micropipettes. The strength of the skin was also studied by stabbing a colony held in place by gentle suction of the larger pipette with a glass tube of $4 \mu \mathrm{m}$ outer diameter from the opposite end.

Transfer for staining, exposure and permeability experiments. For staining or permeability measurements transfer of single colonies from the medium to the experimental solution and back is necessary. The principle of the transfer experiments (Evans 1989) is shown in Fig. 2. A split double chamber was used. Both chambers were separated by a narrow air gap. In order to transfer a colony 2 pipettes were employed. The socalled transfer pipette had a much larger inner dia-

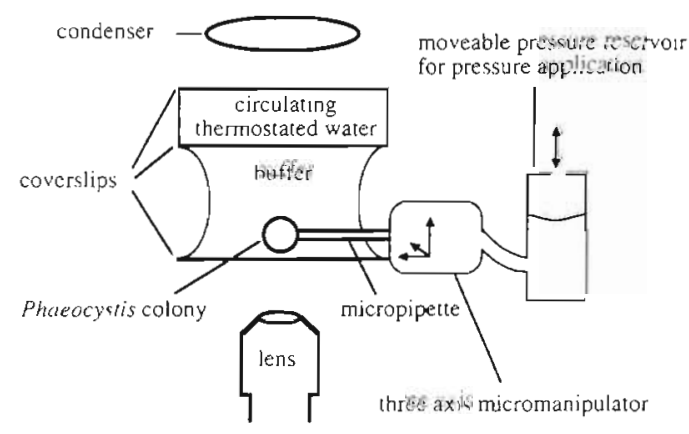

Fig. 1. Schematics of the micropipette setup, not to scale 


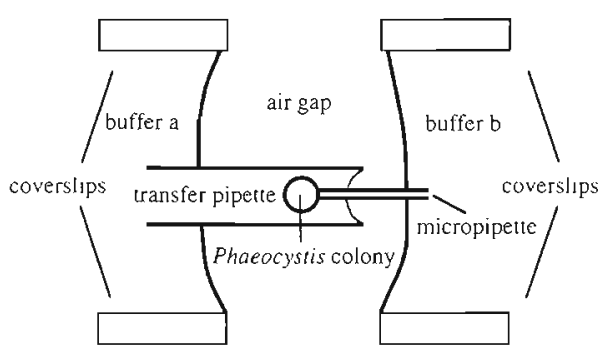

Fig. 2. Schematic view of a transfer experiment

meter than the usual pipettes and was filled with the experimental solution as well. After aspiration of a suitable colony with the measuring pipette, it was maneuvered into the transfer pipette. This assembly was then moved through the air gap by moving the microscope stage with the colony protected from air by the transfer pipette. Subsequently the colony was removed from the transfer pipette in the second chamber and moved several millimeters away from the air gap. The amount of medium co-transferred during the procedure was negligible for the experiments described here.

Permeability tests. Permeability was tested by transferring single colonies from natural seawater with an osmolarity of $982 \mathrm{mOsm}$ into solutions of different compositions and osmolarities. These were deionized water, natural seawater and sucrose (1503 mOsm), natural seawater and dextran 6000 (1584 mOsm), and deionized water and dextran 6000 (183 mOsm). Colonies were exposed to these buffers for approximately 5 min and transferred back into natural seawater. Initial colony contractions, invoked by elevated extracolonial osmotic pressures, were expected to be rapidly reversed if the colony skin was permeable for the compounds causing the pressure difference. Conversely, compounds too large to enter the colony skin were expected to cause persisting shrinkage.

Osmolarities of the solutions used were measured with a freezing point depression osmometer (Microosmometer, model 3MO, Advanced Instruments, Needham Heights, MA). The hydrodynamic radius of dextran was determined by quasi-elastic laser light scattering, also termed 'particle sizing' (Chu 1991). We used a commercial instrument described by Piekenbrock \& Sackmann (1992). Dextran with a molecular weight of $6000 \mathrm{Da}$ (Fluka) was dissolved in distilled water, filtered with a $200 \mathrm{~nm}$ pore filter to remove dust, and measured at scattering angles of $50^{\circ}$ and $90^{\circ}$. The data were analyzed using the contin algorithm (Provencher 1982). At both scattering angles a narrow distribution of sizes centered at $2.2 \mathrm{~nm}$ was found.

Staining. In all cases the colonies were transferred into the staining buffer, left there for approximately
5 min, transferred back and moved away from the transfer pipette. The fluorescent regions within the colony were then immediately examined under the microscope.

Studied constituents: fluorescent probes and staining buffers:

(1) Plasma membrane: Dil (1,1'-dioctadecyl-3, 3, 3', 3'tetramethylindocarbocyanine perchlorate; green excitation) was dissolved at $1 \mathrm{mg} \mathrm{m}^{-1}$ in DMSO (dimethyl sulfoxide, Merck, Darmstadt, Germany) and $50 \mu \mathrm{l}$ of this preparation were added to $1 \mathrm{ml}$ seawater.

(2) Hydrophobic compartments: NBD hexanoic acid (6-(N-(7-nitrobenz-2-oxa-1,3-diazol-4-yl)-amino) hexanoic acid; blue excitation) was dissolved at $1 \mathrm{mg} \mathrm{ml}^{-1}$ in ethanol (Merck) and $50 \mu \mathrm{l}$ of this preparation were added to $1 \mathrm{ml}$ seawater.

(3) Amino groups: TAMRA-SE (5-(and-6)-carboxytetramethylrhodamine succinimidyl ester; green excitation) was dissolved at $1 \mathrm{mg} \mathrm{ml}^{-1}$ in DMSO (Merck) and $50 \mu \mathrm{l}$ of this preparation were added to $1 \mathrm{ml}$ seawater.

(4) Chitin and chitobiose: FITC-labeled WGA (Fluoroescein isothiocyanat-labeled wheat germ agglutinin; blue excitation) was dissolved at $50 \mu \mathrm{g} \mathrm{ml}^{-1}$ in seawater.

All fluorescent probes (except WGA) were purchased at Molecular Probes (Eugene, OR) and used as received. WGA was obtained from Sigma, Deisenhofen, Germany.

Exposure experiments. Detergent treatment was also performed as a transfer experiment. Colonies were transferred from seawater into a $3 \%(\mathrm{w} / \mathrm{w})$ solution of the detergent n-octylpolyoxipropylene (Sigma, Deisenhofen, Germany) in seawater, left there for approximately $5 \mathrm{~min}$ and transferred back. Colonies were also exposed to a saturated solution $\left(280 \mathrm{~g} \mathrm{l}^{-1}\right)$ of Na-EDTA (ethylenediaminetetraacetic acid, Sigma) titrated to seawater equivalent $\mathrm{pH} 8.2$ with $\mathrm{KOH}$.

\section{RESULTS}

\section{Colony structure}

The series of events recorded during a representative aspiration experiment is shown in Fig. 3. At first, the outer skin of the colony together with 1 cell entered the pipette, the remaining cells clumped into a pouch at the other end. The skin was tightly pressed against the cells and became invisible, its presence and location can be inferred from the outer margins of the cells inside and outside the pipette. The obvious loss in colony volume indicates rapid expulsion of water through the skin. Increasing suction dislodged cells individually from the pouch which tightened simultaneously. The cells were greatly elongated during pas- 

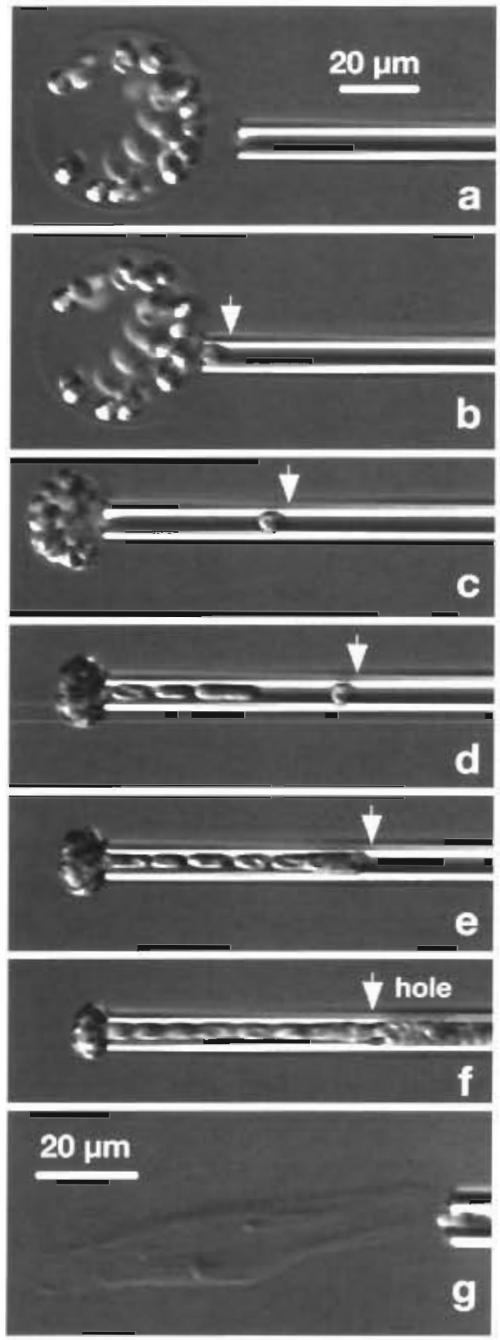

Fig. 3. Sequence of high pressure aspiration of a Phaeocystis colony (diameter ca $50 \mu \mathrm{m}$ ). (a) colony and pipette before aspiration, (b) commencement of aspiration, (c) a single cell entering the pipette, colony volume outside has significantly decreased, (d) additional cells, highly deformed by the extreme pressure gradient, entering the pipette; the initial cell remains in a stationary position, (e) buildup of the pressure head indicated by deceleration of the following cells, and extreme bunching of the cells outside which prevent their suction into the pipette, (f) rupture of the tip of the skin within the pipette with cells passing through the hole (marked by the arrow), (g) shows the tube-shaped empty colony skin (lateral view). Note the abundant longitudinal folds on the skin and the absence of visible space attributable to a firm gelatinous matrix within the colony immediately prior to its rupture

sage but squeezed together against the skin in the pipette. As cells are usually not or only barely compressible (Evans 1989) a very high tension developed in the skin. The entire discernible volume of the colony now comprised only the cells. Finally, the outermost extremity of the skin ruptured and all the cells were sucked out of the hole. The tip of the skin inside the
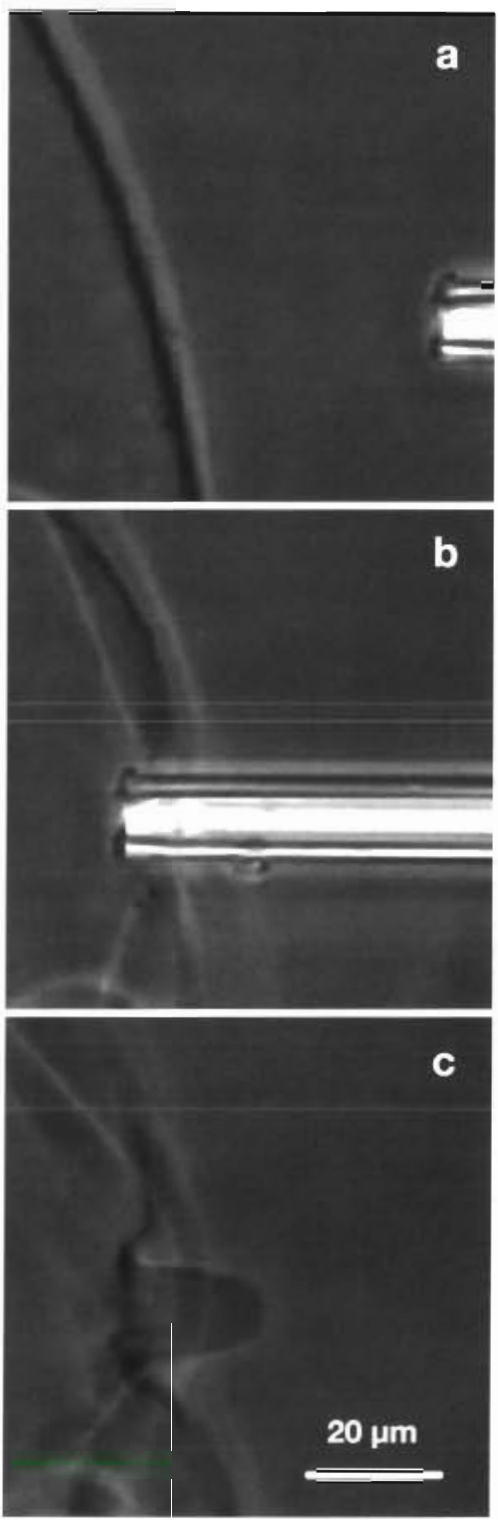

Fig. 4. A large Phaeocystis colony (ca $500 \mu \mathrm{m}$ ): (a) before aspiration, (b) during aspiration, and (c) after release

pipette remained more or less stationary till breakage, indicating that the skin is not distendable. On exhaling the contents of the pipette, the skin, followed by the individual cells, emerged as an empty, transparent, bag-like structure. Although its thickness was well below $1 \mu \mathrm{m}$, it appeared to be fairly stiff as it retained the shape it had on emerging from the pipette despite considerable movement in the agitated medium. There was no indication of the presence of any firm gelatinous matter either during compression of the colony or following exhalation of the contents of the colony.

Nine colonies of different sizes were tested with the microaspirator. Three smaller colonies $(<50 \mu \mathrm{m})$ were 
each sucked into the pipette without skin breakage, and emerged following exhalation in rod shape with serially oriented cells. Within $30 \mathrm{~min}$, these compressed colonies approximately doubled their diameter. All 4 medium-sized colonies (50 to $100 \mu \mathrm{m}$ ) behaved exactly as described above (Fig. 3). The 2 larger colonies (150 and $500 \mu \mathrm{m}$ ) withstood the maximum suction of about several $10000 \mathrm{~Pa}$ (several Newton $\mathrm{cm}^{-2}$ ) without breakage; only a nipple was drawn into the pipette (Fig. 4) which retained its shape after pressure release. Slight relaxation of the nipple shape commenced some 10 s later.

The strength of the skin was also studied by stabbing a colony held in place by gentle suction of the larger pipette with a tube of $4 \mu \mathrm{m}$ outer diameter from the opposite end (Fig. 5). The skin withstood the pressure of being pushed through the colony. Retraction of the pipette left a deep crater-like pit that slowly filled out again after some seconds. The skin broke only after the pipette pushed through the skin inside the larger pipette. Skin breakage resulted in rapid disorganisation of the colony contents.

While the characteristics of the skin around intact Phaeocystis colonies are difficult to define optically because of its transparency and its thinness, its pres-
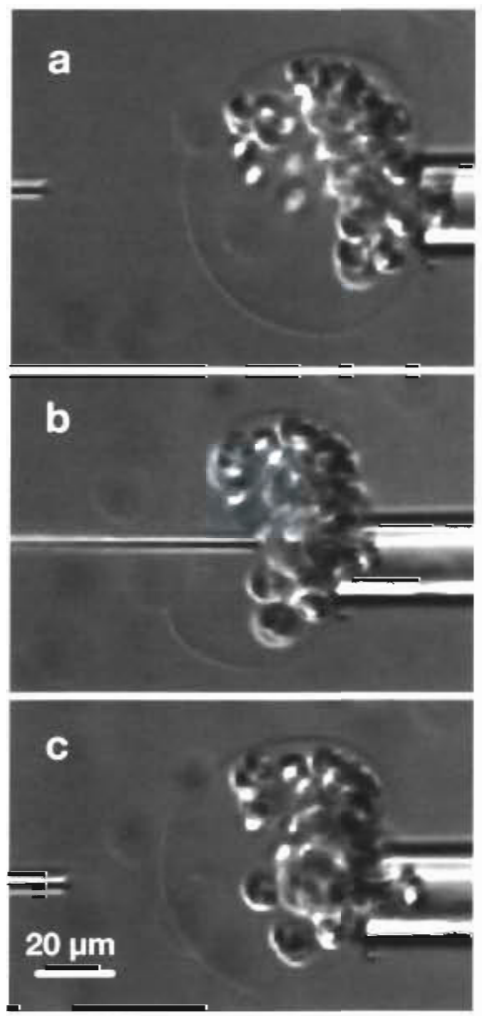

Fig. 5. Failed attempt to pierce the skin with a pipette: (a) before, (b) during, (c) and after the attack. Note that the pipette was rapidly stabbed into the Phaeocystis colony
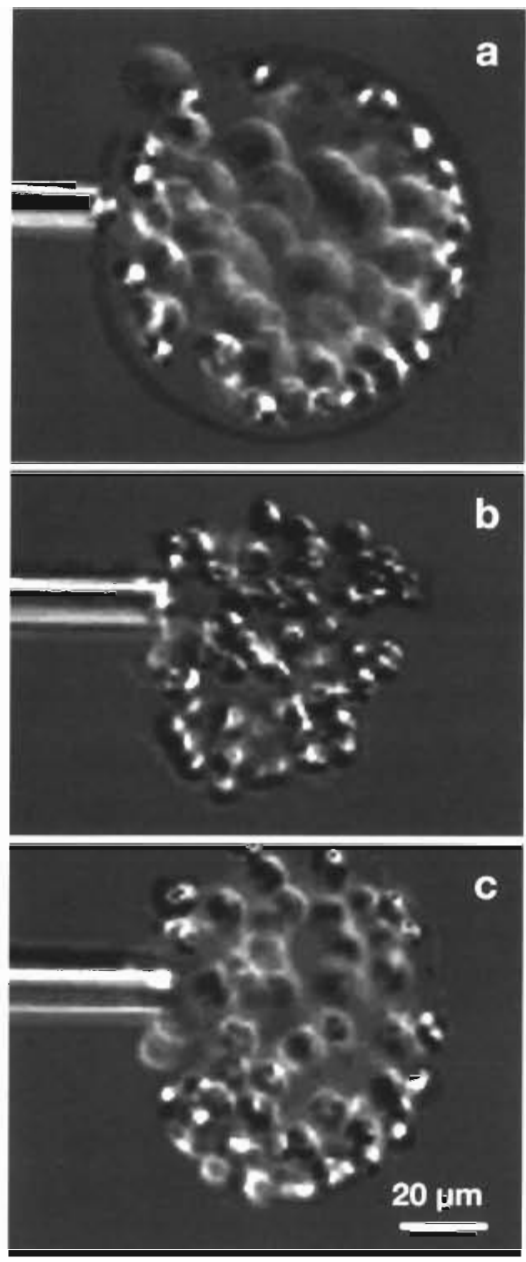

Fig. 6. Effect of transfer of a Phaeocystis colony into a hyperosmotic solution of dextran in seawater. The same colony in (a) seawater, (b) after transfer into a solution of dextran 6000

in seawater and (c) after transfer back into seawater

ence can be well discerned under DIC field. However, its thickness could not be resolved by light microscopy, and its presence as a determinate structure could only be examined following removal of its contents which proved its autonomy and indicated it to be a plastic deformable structure.

The colony skin was found to be permeable for inorganic ions and small organic molecules, but impermeable for large organic molecules. This was inferred from the following effects:

(1) Transfer of Phaeocystis colonies from seawater to deionized water had no visible effect on the colony skin, but a rapid decrease of intracolonial osmolarity could be inferred from the rapid swelling and bursting of the colonial cells. This implies that inorganic ions pass freely through the colony skin. (2) Transfer of Phaeocystis colonies to a hyperosmotic solution (1503 mosm) containing seawater and sucrose (MW = 
186, hydrodynamic radius $0.47 \mathrm{~nm}$. Weast 1970) caused a brief contraction of the colonies which lasted for approximately $2 \mathrm{~s}$. This indicates that the colony skin is permeable for sucrose, thus it must contain pores larger than $1 \mathrm{~nm}$. (3) Transfer of Phaeocystis colonies to a hyperosmotic solution (1584 mOsm) containing seawater and dextran ( $\mathrm{MW}=6000$, hydrodynamic radius $2.2 \mathrm{~nm}$ ) caused rapid colony shrinkage to a considerably reduced size (Fig. 6). The compression was not reversed while the colony stayed in this solution (several minutes), which indicates that the colony skin was completely impermeable for dextran 6000. Hence the largest pores of the colony skin were smaller than $4.4 \mathrm{~nm}$. Reinflation of the colony after retransferring it to the original seawater (Fig. 6c) confirmed this, and indicated the presence of large osmolytes in the colony. (4) Transfer of Phaeocystis colonies into a hypoosmotic solution (183 mOsm) containing deionized water and dextran $(\mathrm{MW}=6000)$ led to a rapid shrinkage of the colony. This was followed by swelling and bursting of the cells and a simultaneous reinflaton of the colony, indicating that the cells contained enough large soluble molecules to increase turgor and overcome plastic deformation. The skin was permeable for all other chemical compounds used in our study, because the cells were affected (lysed or dyed) by all of them.

A dilute gel layer of several micrometer thickness underlies the skin. Direct imaging of this layer was only possible for large $(500 \mu \mathrm{m})$ colonies, where it appeared as a slightly darker zone in the colony periphery in phase contrast micrographs. Since the gel layer was not visibly stained with any of the fluorescent probes used in this study, and the colonies could be compressed until virtually no space was left between the cells and the colony skin (Fig. 3), the gel layer cannot be very substantial. Individual cells appear to be connected by a highly elastic structure, as pulling out 1 cell from a ruptured colony resulted in its being followed by other cells. The connection presumably consists of thread-like links. The adhesion of the colonial cells to the gel must be very weak because it could be broken by the viscous drag (estimated, according to Stokes law, to approx. $1 \mathrm{pN}$ ) of the cells outside the skin. Visible Brownian motion of single colonial cells relative to each other confirms that the cells must be held by a very flexible structure. The recovery of original shape after deformation implies that the interior of the colony is filled with seawater and some large-molecular osmolytes.

\section{Biochemical composition}

Immersion in the detergent $\mathrm{n}$-octylpolyoxipropylene rapidly resulted in disintegration of the cells inside the colony, but had no effect on colony shape (Fig. 7), suggesting that lipids are the dominant structurestabilizing compounds of the cells, but not of the colony skin. However, the colonies strongly adhered to hydrophobic polystyrene surfaces of Petri dishes used for independent colony observation during the study, implying that the colony surface is hydrophobic. Yet, both lipid dyes did not label the colony surface. The amphiphilic fluorescent probe DiI is known to selectively label the plasma membrane of eucaryotic cells and is widely used for this type of experiment (Haugland 1996). The dye NBD-hexanoic acid is poorly soluble in water and therefore should be enriched in hydrophobic compartments. Both dyes stained exclusively the colonial cells. Dil labeled the plasma membrane only (Fig. 8a), NBD-hexanoic acid the internal membranes as well (data not shown). From this finding we conclude that the skin neither contains hydrophobic compartments (e.g. droplets) in more than trace amounts, nor an amphiphilic layer like a lipid membrane.

Succinimidyl ester, the reactive group of TAMRA$\mathrm{SE}$, attacks free amino groups (e.g. lysine residues in proteins) and forms stable chemical bonds with them. The optimum pH for this reaction is around 8.5, close to
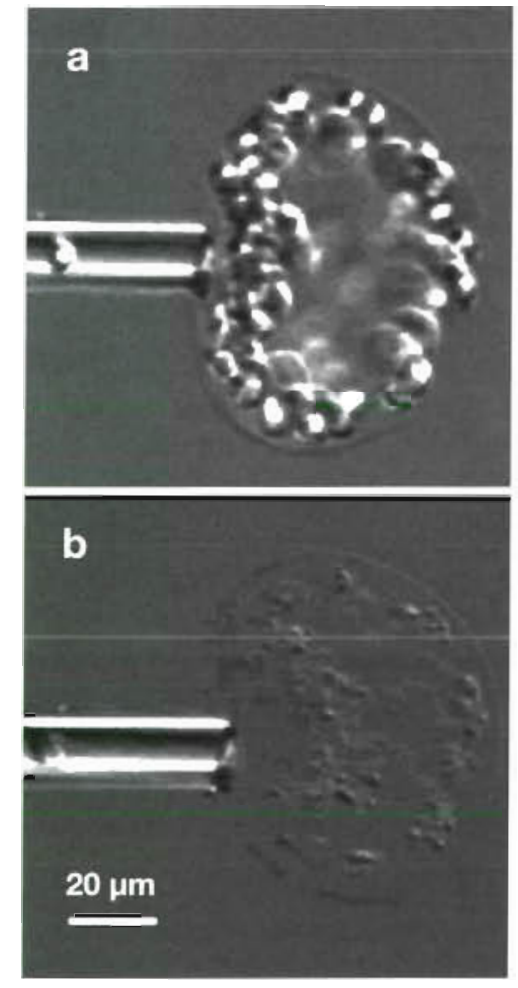

Fig. 7. Transfer of (a) an intact Phaeocystis colony into (b) the detergent n-octylpolyoxipropylene, resulting in rapid cell disintegration. The cell in the pipette was affected approximately 6 s later 

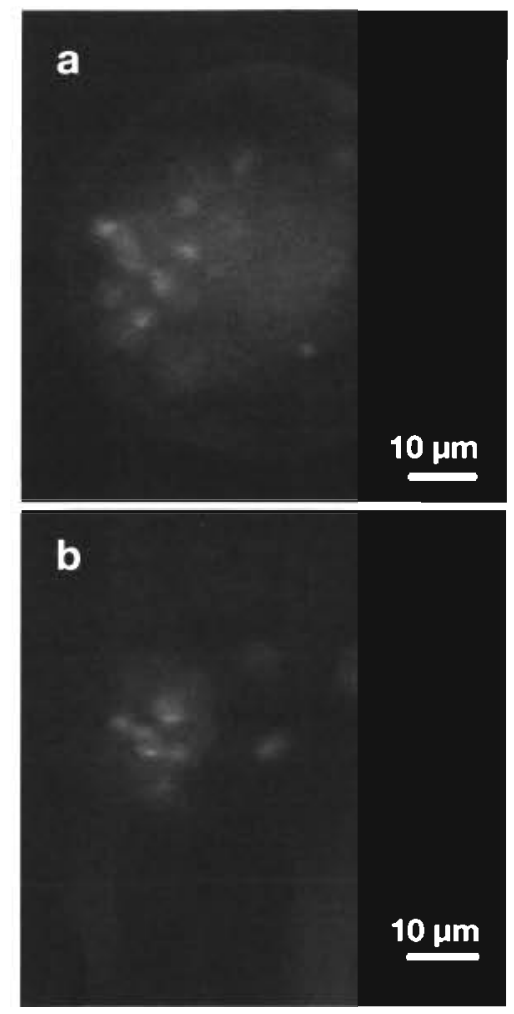

Fig. 8. Fluorescence micrographs of (a) a Phaeocystis colony that was stained with TAMRA-SE with a clearly visible colonial skin, and (b) a colony of the same size after staining with DiI, only the cells were labeled

the $\mathrm{pH}$ of seawater (Haugland 1996). The distinct labeling of both cells and skin by TAMRA-SE (Fig. 8b) shows that the Phaeocystis colony skin contains amino groups in high density. FITC-labelled lectin WGA which binds to chitin and chitobiose in seawater, (Montgomery et al. 1990), labelled only the colony cells, but not the skin. Thus, chitin is not present in the skin, and the amino groups most likely due to amino acids present as proteins in the colony skin.

Transfer of colonies into deionized water or highly concentrated EDTA solutions resulted in cell disintegration, but the skin and colony shape remained optically unchanged (data not shown). Thus, calcium bridges are not crucial for maintaining the integrity of the outer skin on a time scale of minutes.

\section{DISCUSSION}

The presence of a thin, tough skin encasing the Phaeocystis colony was not suspected when we commenced the experiments. Our findings now show that the skin must function as a highly effective defence against a wide range of planktonic grazers but also bacterial and viral pathogens. In view of the fact that cell growth rates within colonies are similar to those of solitary cells, it would appear that skin formation is not unduly costly. Further, colony cells do not possess flagellae, scales or chitin fibrils typical for the solitary form (Baumann et al. 1994), which would free additional resources for skin formation. Although we studied only the warm-water species Phaeocystis globosa, it can be assumed that the properties we describe are common to the other colonial species $P$. pouchetti and $P$. antarctica as their colonies are superficially very similar and both species are reported to have evolved from P. globosa (Medlin et al. 1994). We argue below that protection by the skin is the key factor responsible for the extraordinary ecological success of this genus, enabling its colonial form to regularly build up extensive blooms in very diverse oceanic regimes (Verity \& Smetacek 1996).

\section{The colony skin as a grazer deterrent}

Colonial organisation has been suggested to protect Phaeocystis cells against grazing (Weisse et al. 1994, and reference therein) although the nature of the protective mechanisms other than increase in size was not specified. Current knowledge on the mechanical properties of Phaeocystis colonies is controversial. It has been hypothesized that protection is of mechanical nature (e.g. Smaal \& Twisk 1997). Whereas some studies suggest that Phaeocystis colonies are resistant to disruption (e.g. Schnack et al. 1985), others imply that the colonies are fragile (Cariou et al. 1994, Hansen et al. 1994). Attempts to pierce a large Phaeocystis colony with a needle failed and created a folded dent (Kornmann 1955), but Phaeocystis colonies are reported to have been successfully penetrated with microelectrodes (Lubbers et al. 1990). Our results indicate a high resistance of the colony to suction pressure and piercing even with very pointed objects.

It is now known that the major grazers of phytoplankton are heterotrophic protists which feed by very different mechanisms (Schnepf \& Elbrächter 1992). The most common types ingest their prey and would be deterred by large prey size. However, those groups which feed by enveloping food items in a feeding veil (the pallium) or penetrate it by means of peduncles and similar extensible structures can overcome the size barrier and feed efficiently on much larger prey, in particular diatoms. However, we know of no reports of protists feeding on intact, healthy Phaeocystis colonies. In contrast, cells in disintegrating colonies and single cells are readily eaten by various protists (e.g. Admiraal \& Venekamp 1986, Estep et al. 1990, Weisse \& Scheffel-Moeser 1990, van Boekel et al. 1992). Solitary 
cells are also susceptible to bacterial and viral attack (Thingstad \& Billen 1994, Jacobsen et al. 1996) but cells in colonies appear to be more or less immune to pathogens. Hence, when colony cells migrate out of the colonies following peaking of the bloom, Phaeocystis biomass rapidly declines due to grazing pressure and cell mortality. Our findings strongly suggest that mechanical protection by the tough skin with its small pore size is the major reason for low mortality of colony cells rather than chemical protection by means of deterrents such as acrylic acid derived from the breakdown of DMSP (sensu Wolfe et al. 1996) or poor nutritional value of the cells (sensu Claustre et al. 1990 or Nicols et al. 1991).

Larger zooplankton such as euphausiids and large copepods are reported to feed readily on Phaeocystis colonies (Weisse et al. 1994) presumably because they possess the means (gastric mills and sharp mandibles respectively) to rupture the skin. Mechanical protection is also indicated by size dependent ingestion of Phaeocystis colonies by different developmental stages of Calanus finmarchicus (Hansen et al. 1990): while small copepodites (C1 to C3) ingested large $(>100 \mu \mathrm{m})$ colonies less effectively than diatoms or smaller colonies, larger copepodites (C4 \& C5) did not select against large Phaeocystis colonies. However, even these large forms are likely to be deterred by colonies because they will have to cope with the large amount of water within it. Such an increase in handling time will also help in reducing grazing and hence mortality rate. As the larger grazers are now known to consume only a small percentage of the phytoplankton, their feeding pressure will not suffice to prevent a bloom from building up.

\section{Structure}

The structure of Phaeocystis colonies has been discussed since the last century (see van Rijssel et al. 1997 and reference therein). Lagerheim (1896) proposed that the colonies are enclosed in a thin, but dense skin, lined from the inside with a loose gel in which the ceils are located and with the colony lumen devoid of solid matter. In contrast, Scherffel (1900) assumed that the whole colony was gelatinous. As the presence of a skin is not evident under scrutiny with a microscope, it has been widely assumed that the shape and firmness of the colonies is due to a homogeneous matrix of gelforming mucopolysaccharides (Lancelot et al. 1998). Presumably, the view of a firm gelatinous consistency was also supported by the fact that colonies can attain $10 \mathrm{~mm}$ diameter and still retain their shape. However, it has been recently shown that polysaccharides are concentrated in a relatively thin layer around the periphery of the colonies (van Rijssel et al. 1997). As we were only able to separate the skin from colonies below $100 \mu \mathrm{m}$ diameter, it is possible that larger colonies accumulate more polysaccharides over time; nevertheless the larger colonies we manipulated also possessed the skin which in itself, combined with internal turgour, would suffice to maintain the characteristic smooth, spherical appearance of the colonies and their resistance to attack by the wide variety of grazers in pelagic systems.

Our results support the colony structure proposed by Lagerheim (1896). It was not possible to determine the thickness of the skin with the methods we used. While van Rijssel et al. (1997) found a $8 \mu \mathrm{m}$ thick layer where FITC-labeled Con-A bound to the skin, this study suggests that the mechanically tough and optically dense skin has a thickness well below $1 \mu \mathrm{m}$ (Fig. 3a). However, this is not necessarily a contradiction, as the visibly stainable material might extend further into the colony than the very dense and mechanically tough outer layer. The existence of a dilute gel layer in the colony periphery as proposed here and mentioned by Lagerheim (1896), Kornmann (1955) and van Rijssel et al. (1997) would explain the low optical density, elasticity, and connective properties of this region observed by us.

\section{Biochemical composition}

Hydrophobicity of the colony skin has been observed by Janse (pers. comm.), and inferred from stronger adhesion of the colonies to polystyrene surfaces than to glass surfaces. As specific dyes indicated the absence of lipid in the skin, polysaccharides or proteins must be responsible for the adsorption of Phaeocystis colonies to hydrophobic surfaces. For instance, many proteins strongly absorb to polystyrene, which is used for immunoassays in polystyrene microtiterplates. In contrast to our expectations, $\mathrm{Ca}^{2+}$, which has been shown to be important for colony formation (van Boeckel 1992), was not essential in maintaining their structural integrily.

The amino groups we found to be compounds of the colony skin could be derived from various sources, the most likely candidates being amino sugars and amino acids. The presence of chitin, which has been shown to form the fibrils of the Phaeocystis flagellates (Chretiennot-Dinet et al. 1997), can be excluded because the colony skin was not stained by FITC-labeled lectin WGA (Montgomery et al. 1990). Likewise, glucosamine, which is a structure-building component in cell walls of some green algae (e.g. Takeda 1991), has not been found in Phaeocystis colonies (Janse et al. 1996). Under the assumption that the colony skin of Phaeocystis has 
a certain similarity to cell walls (see below), the detected amino groups could belong to proteins like the extensins, which have been found in the colonial freshwater alga Volvox (Ertl et al. 1989). An alternative explanation for our results could be that the mechanically tough structure is coated with a thin layer of different materials containing aminogroups (e.g. a carbohydrate layer coated with protein slime) or consists of glycoproteins

\section{Mechanical properties}

In spite of its thinness, the outer skin is a very tough structure. Extreme forces were necessary to rupture the colony skin (Figs. 3 to 5 ). A similar observation was reported by Kornmann (1955). We observed predominantly plastic behavior of the skin, but reversible deformations and the formation of folds (Figs. 3 to 5) indicates a certain degree of stiffness (elasticity), therefore the reaction of the skin to mechanical deformation is elastoplastic. In contrast to the skin, the gel layer and the cell-cell connections appear to be mainly elastic.

While we could relate the colony structure to a protective function, the molecular structures of the colony architecture as well as development and growth of the colony skin are not known. It is of interest to note that some properties of the Phaeocystis colony, i.e. the mechanical properties (toughness and elasticity), pore sizes between 1 and $4 \mathrm{~nm}$, sugar composition (Janse et al. 1996), the potential presence of a structural protein, and the potential to produce intracolonial osmotic pressure with large organic molecules (Veldhuis \& Admiraal 1985) resemble typical features of plant cell walls (see Kutschera 1996 for mechanical properties, Alberts et al. 1983 for sugar composition and pore size, Mc Queen-Mason 1995 for growth by osmotic pressure). Thus, the cell wall might serve as a model for further studies on the Phaeocystis colony skin.

\section{Ecological and biogeochemical implications}

In the following, we list some of the impacts of Phaeocystis blooms that differentiate them from other phytoplankton: (1) formation of large blooms also in the absence of silica (Smith et al. 1991), (2) low abundance of micro- and small mesozooplankton during blooms (van Boekel et al. 1992), (3) efficient sedimentation of Phaeocystis-derived organic matter in faecal material of large zooplankton (Hamm et al. unpubl. res.), but not in aggregates (Riebesell 1993), (4) rapid decline of the bloom once the colonies start breaking up (Davies et al. 1992), coinciding with (5), increase of the microbial commu- nity and massive cell lysis (van Boekel 1992, Brussaard et al. 1995), potentially as a result of microbial (viral!) activity (Jacobsen et al. 1996) accompanied by buildup of dissolved organic matter in the water column (Eberlein 1985, Davidson \& Marchant 1993), and (6) formation of surface slicks and foams at the water surface (Lancelot et al. 1998, Hamm \& Rousseau unpubl. res.). We conclude that the presence of a colony skin - which protects otherwise susceptible colony cells from mortality and that is discarded following the bloom peakmight be largely responsible for these unique ecological and biogeochemical characteristics of Phaeocystis blooms. To our knowledge, this is the first report of an algal colony skin tough enough to provide effective refuge to the enclosed cells.

Acknowledgements. We thank Anke Dauelsberg for supplying the Phaeocystis globosa strain, Tobias Storz for measuring the hydrodynamic radius of dextran 6000, and Erich Sackmann for generous support. Sven Günther, Dieter WolfGladrow and 4 anonymous reviewers provided valuable comments on the manuscript. This work was funded by the Deutsche Forschungsgemeinschaft via the group grant Sonderforschungsbereich 266 and by the Alfred Wegener Institute for Polar and Marine Research. This is publication No. 1620 of the Alfred-Wegener-Institute for Polar and Marine Research

\section{LITERATURE CITED}

Admiraal W, Venekamp LAH (1986) Significance of tintinnid grazing during blooms of Phaeocystis pouchetti (Haptophyceae) in Dutch coastal waters. Neth J Sea Res 20:61-66 Alberts B, Bray D, Lewis J, Raff $M$, Roberts K, Watson JD (1983) Molecular biology of the cell. Garland, New York

Baumann MEM, Lancelot C, Brandini FP, Sakshaug E, John DM (1994) The taxonomic identity of the cosmopolitan prymnesiophyte Phaeocystis: a morphological and ecophysiological approach. J Mar Syst 5:5-22

van Boekel WHM (1992) Phaeocystis colony mucus components and the importance of calcium ions for colony stability. Mar Ecol Prog Ser 1981:301-305

van Boekel WHM, Hansen FC, Riegman R, Bak RPM (1992) Lysis-induced decline of a Phaeocystis spring bloom and coupling with the microbial foodweb. Mar Ecol Prog Ser 81:269-276

Brussaard CPD, Riegman R, Noordeloos AAM, Cadée GC, Witte H, Kop AJ, Nieuwland G, van Duyl FC, Bak RPM (1995) Effects of grazing, sedimentation and phytoplankton cell lysis on the structure of a coastal pelagic food web. Mar Ecol Prog Ser 123:259-271

Cariou V, Casotti R, Birrien JL, Vaulot D (1994) The initiation of Phaeocystis colonies. J Plankton Res 16:457-470

Chretiennot-Dinet MJ, Girauld-Guille MM, Vaulot D, Putaux JL, Saito Y, Chanzy H (1997) The chitinous nature of filaments ejected by Phaeocystis (Prymnesiophyceae). J Phy$\operatorname{col} 33: 666-672$

Chu B (1991) Laser light scattering, 2nd edn. Academic Press, San Diego, CA.

Claustre H, Poulet SA, Williams R, Marty JC, Coombs S, Ben Mlih F, Hapette AM, Martin-Jezequel V (1990) A biochemical investigation of a Phaeocystis sp. bloom in the Irish Sea. J Mar Biol Assoc UK 70:197-207 
Davidson AT, Marchant HJ (1992) Protist abundance and carbon concentration during a Phaeocystis-dominated bloom at an Antarctic coastal site. Polar Biol 12:387-395

Davies AG, de-Madariaga I, Bautista B, Fernandez E, Harbour DS, Serret P, Tranter PRG (1992) The ecology of a coastal Phaeocystis bloom in the north-western English Channel in 1990. J Mar Biol Assoc UK 72:691-708

Eberlein K, Leal MT, Hammer KD, Hickel W(1985) Dissolved organuc substances during a Phaeocystis pouchetii bloom in the German Bight (North Sea). Mar Biol 89:311-316

Ertl H, Hallmann A, Wenzl S, Sumper M (1992) A novel extensin that may organize extracellular matrix biogenesis in Volvox carteri. EMBO J: 11:2055-2062

Estep KW, Nejstgaard JC, Skjoldal HR, Rey F (1990) Predation by copepods upon natural populations of Phaeocystis pouchetii as a function of the physiological state of the prey. Mar Ecol Prog Ser 67:235-249

Evans EA (1989) Structure and deformation properties of red blood cells. Concepts and quantitative methods. Methods Enzymol 173:3-35

Grimm N, Weisse T (1985) Die Temperaturabhängigkeit des Wachstums von Phaeocystis pouchetii (Haptophyceae) in Batchkulturen. Helgol Wiss Meeresunters 39:201-211

Guillard RRL, Ryther JH (1962) Studies of marine planktonic diatoms. I. Cyclotella nana Hustedt and Detonula confervacea Cleve. Can J Microbiol 8:229-239

Guillard RRL, Hellebust JH (1971) Growth and the production of extracellular substances by two strains of Phaeocystis pouchetii. J Phycol 7:330-338

Hansen B, Tande KS, Berggreen UC (1990) On the trophic fate of Phaeocystis pouchetii (Hariot). 3. Functional responses in grazing demonstrated on juvenile stages of Calanus finmarchicus (Copepoda) fed diatoms and Phaeocystis J Plankton Res 12:1173-1187

Hansen B, Verity P, Falkenhaug T, Tande KS, Norrbin $F$ (1994) On the trophic fate of Phaeocystis pouchetti (Harriot). 5. Trophic relationships between Phaeocystis and zooplankton: An assessment of methods and size dependence. J Plankton Res 16:487-511

Haugland. RP (1996) Handbook of fluorescent probes and research chemicals ( 6 th edn). Molecular probes, Eugene, OR

Jacobsen A, Bratbak G, and Heldal M (1996) Isolation and characterization of a virus infecting Phaeocystis pouchetil (Prymnesiophyceae). J Phycol 32:923-927

Janse I, van Rijssel. M, Gottschal JC, Lancelot C, Gieskes WWC (1996) Carbohydrates in the North Sea during spring blooms of Phaeocystis: a specific fingerprint. Aquat Microb Ecol 10:97-103

Kornmann, P (1955) Beobachtungen an Phaeocystis-Kulturen Helgol Wiss Meeresunters 5:218-233

Kutschera U (1996) Cessation of cell elongation in rye coleoptiles is accompanied by a loss of cell-wall plasticity. J Exp Bot 47:1387-1394

Lagerheim, G (1896) Über Phaeocystis poucheti (Har.) Ldqerh., eine Plankton-Flagellate. Ofvers af Vet Akad Förhandl 4:277-288

Lancelot C, Rousseau V (1994) Ecology of Phaeocystis ecosys tems: the key role of colony forms. In: Green J, Leadbeter BSC (eds) The haptophyte algae. Clarendon Press, Oxford, p $229-245$

Lancelot C, Keller MD, Rousseau V, Smith, WO Jr, Mathot S (1998) Autecology of the marine haptophyte Phaeocystis sp. In: Anderson DM. Cembella AD. Hallegraeff GM (eds) Physiological ecology of harmful algal blooms. NATO ASI Series G41:209-224

Lubbers GW, Gieskes WWC, del Castilho P, Salomons W, Bril $\mathrm{J}$ (1990) Manganese accumulation in the high $\mathrm{pH}$ micro- environment of Phaeocystis sp. Haptophyceae colonies from the North Sea. Mar Ecol Prog Ser 59:285 293

Mc Queen-Mason SJ (1995) Expansins and cell. wall expansion. J Exp Bot 46:1639-1650

Medlin LK, Lange M, Baumann MEM (1994) Genetic differentiation among three colony-forming species of Phaeocystis: further evidence for the phylogeny of the Prymnesiophyta. Phycologia 33:199-212

Mitchison JM, Swann MM (1954) The mechanical properties of the cell surface. I. The cell elastimeter. J Exp Biol 31: $443-460$

Montgomery MT, Welschmeyer NA, Kirchman DL (1990) A simple assay for chitin: application to sediment trap samples from the subarctic Pacific. Mar Ecol Prog Ser 64: 301-308

Needham D (1993) Measurement of interbilayer adhesion energies. Methods Enzynol 220:111-129

Nichols PD, Skerratt JH, Davidson A, Burton H, McMeekin TA (1991) Lipids of cultured Phaeocystis pouchetii : signatures for food-web, biogeochemical and environmental studies in Antarctica and the Southern Ocean. Phytochemistry 30:3209-3214

Piekenbrock T, Sackmann E (1992) Quasielastic light scattering study of thermal excitations of $f$-actin solutions and growth kinetics of actin filaments. Biopolymers 32: 1471-1489

Provencher S (1982) CONTIN: a general purpose constraint regularization. Method Comput Phys 27:229-242

Rand RP, Burton AC (1964) Mechanical properties of the red cell membrane. I. Membrane stiffness and intracellular pressure. Biophys J 4:115-135

Riebesell U (1993) Aggregation of Phaeocystis during phytoplankton spring blooms in the southern North Sea. Mar Ecol Prog Ser 96:281-289

Rijssel M van, Hamm CE, Gieskes WWC (1997) Phaeocystis globosa (Prymnesiophyceae) colonies: hollow structures built with small amounts of polysaccharides. Eur J Phycol 32:185-192

Scherffel A (1900) Phaeocystis globosa n. sp. nebst einigen Betrachtungen über die Phylogenie niederer, insbesondere brauner Organismen. Helgoland Wiss Meeresunters 4:1-29

Schnack SB, Smetacek V, von Bodungen B, Stegmann P (1985) Utilisation of phytoplankton by copepods in Antarctic waters during spring. In: Gray JS, Christiansen ME (eds) Marine biology of polar regions and effects of stress on marine organisms. Whiley, Chichester, p 11-17

Schnepf E, Elbrächter $M$ (1992) Nutritional strategies in dinoflagellates. A review with emphasis on cell biological aspects. Europ J Protistil 28:3-24

Smaal AC, Twisk F (1997) Filtration and absorption of Phaeocystis cf. globosa by the mussel Mytilus edulis L. J Exp Mar Biol Ecol 209:33-46

Smith WO Jr, Codispoti LA, Nelson DM, Manley T, Buskey EJ, Niebauer H.J, Cota GF (1991) Importance of Phaeocystis blooms in the high-latitude ocean carbon cycle. Nature $352: 514-516$

Takeda H (1991) Sugar composition of the cell wall and taxonomy of Chlorella (Chlorophyceae). J Phycol 27:224-232

Thingstad F, Billen G (1994) Microbial degradation of Phaeocystis material in the water column. J Mar Syst 5:55-65

Veldhuis MJW. Admiraal W (1985) Transfer of photosynthetic products in gelatinous colonies of Phaeocystis pouchetii (Haptophyceae) and its effect on the measurement of excretion rate. Mar Ecol Prog Ser 26:301-304

Verity PG. Smetacek V (1996) Organism life cycles, predation, and the structure of marine pelagic ecosystems. Mar Ecol Prog Ser 130:277-293 
Weast RC (1970) Handbook of chemistry and physics. The chemical rubber company, Cleveland, Ohio

Weisse T, Scheffel-Moeser U (1990) Growth and grazing loss rates in single-celled Phaeocystis sp. (Prymnesiophyceae) Mar Biol 106:153-158

Editorial responsibility: Otto Kinne (Editor),

Oldendorf/Luhe, Germany
Weisse T, Tande K, Verity P, Hansen F, Gieskes W (1994) The trophic significance of Phaeocystis blooms. J Mar Syst 5: $67-79$

Wolfe GV, Steinke M, Kirst GO (1997) Grazing-activated chemical defence in a unicellular marine alga. Nature 387:894-897

Submitted: November 24, 1998; Accepted: April 12, 1999

Proofs received from author(5): September 24, 1999 